\title{
Decision Support System for Green Supplier Selection Using the Fuzzy Inference System Method in Abrasive Companies
}

\author{
Defi Norita ${ }^{1}$, Ririn Regiana Dwi Satya ${ }^{2 *}$, Andary Asvaroza Munita ${ }^{3}$ and \\ Asep Endih Nurhidayat ${ }^{4}$
}

\section{1,3 Industrial Engineering Department, Faculty of Engineering, Mercu Buana University, Jakarta Indonesia 2,4 Industrial Engineering Department, Faculty of Engineering and Computer Science, Indraprasta University PGRI, Jakarta Indonesia}

E-mail: defi.norita@mercubuana.ac.id; ririn_regiana@unindra.ac.id; Andary.asvaroza@mercubuana.ac.id; aennoerhidayat@gmail.com

*corresponding author details: Ririn Regiana Dwi Satya; ririn_regiana@unindra.ac.id

\section{ABSTRACT}

The development of information and communication technology makes it easier for users in the industrial world to make decisions in choosing environmentally friendly suppliers more easily. This study aims to determine the selection of green suppliers of all the criteria that have been determined and make a decision support system for selecting green suppliers with the Fuzzy Inference System method. The method used in making identification of green supplier selection is to create criteria based on fuzzy rules and to make digital business modeling using business process modeling notation. Decision support there are 4 criteria used, namely price, reject quality, late delivery and environmental management. Based on the results of research conducted it is known that with the fuzzy inference system method that is assisted using matlab software, the optimization results on the fuzzy inference system show that prices are $20.5 \%$, quality is $5.5 \%$, environment is $5.5 \%$, and material delays are $3 \%$, then supplier performance in selecting green suppliers with a decision making system of $55 \%$ so that green supplier selection is obtained at abrasive companies.

Keywords: Decision Support System; Fuzzy Inference System; Green Supplier Selection

\section{INTRODUCTION}

Along with the development of the industrial world, in recent years consumer concern for the environment has increased from time to time. while there are still producers who do not care about environmental conditions at this time as a result of the production process. The selection of suppliers in the manufacturing industry has a very important role in being able to compete with industry players [1]. Mistakes in selecting suppliers can interfere with company operations [2].

Abrasive company selects suppliers based solely on the aspects of price, delivery and specifications. Abrasive company has not yet entered the environmental aspect into selecting suppliers, this is not in accordance with government regulations regarding the obligations of each industry to pay attention to environmental aspects.

Green supply chain management is a process of using environmentally friendly inputs and converting these inputs into reusable outputs at the end of their life cycle, thus creating a sustainable supply chain. GSCM is an innovation in the application of a supply chain strategy that is based on an environmental context covering several activities such as reduction, recycling, reuse and replacement of materials [3].
A decision support system or Decision support system is a system that is intended to support managerial decision makers in semi-structured decision situations. Decision support systems are intended to be tools for decision makers to expand their capabilities. DSS is intended for decisions that require assessment or unstructured decisions [4].

Fuzzy Inference System is a method that each aims at rules in the form of if-then must be represented by a fuzzy set with the viewing membership function. Fuzzy Inference System is a fuzzy logic concept that emphasizes the inferior system process, namely the processing of data that is owned until a solution is found. Fuzzy inference System consists of 3 types of methods, namely the Tsukomoto Method, the Sugeno Method and the Mamdani Method [5]. The abrasive company cooperates with four suppliers and works quite short, with the longest term being 2 years 2 months. There is one supplier that has not implemented ISO 14000, this is not in accordance with government regulations regarding the obligation of each industry to pay attention to environmental aspects. Each supplier has its own advantages, both in terms of price, reject quality, material delays and environmental management. With the differences in each selection of green suppliers, the company needs a system that is able to support decisions that match the company's needs. 


\section{METHODS}

\section{Decision Support System}

Decision support systems are interactive computer-based systems, which help decision makers to use data and various models to solve unstructured problems. Using a combination of such models, analysis techniques and information retrieval systems helps develop and evaluate suitable alternatives. The implementation of DSS will only be successful if the system is simple and easy to use, easy to supervise, easy to adapt to environmental changes and easy to communicate with various entities [5]. Decision Support Systems are computer-based interactive applications that combine data and mathematical models to help the decision-making process in dealing with a problem [6].

According to [7], fuzzy inference is the process of mapping a number of inputs into output using fuzzy logic, and mapping results become the basis for making a decision. The fuzzy method applied in this study is the Mamdani method with the implication function using the minimum function. The output inference of the FIS Mamdani uses a defuzzification technique that determines the crips value of an output produced. The output of the FIS Mamdani is easily transformed into linguistic form as a conclusion [8]. The FIS Mamdani system consists of four parts [9], as follows:

- Fuzzifier: the membership function shows a collection of fuzzy inputs, which convert the crips input into fuzzy input.

- Rule: the main part of the FIS model is the rule. Fuzzy "ifthen" rules are defined based on the knowledge of experts in each field. The number of fuzzy rules produced will depend on the number of indicators and the number of rating scales. The formulation for determining the number of rules is mathematically stated as:

$$
\sum R=\prod_{i=1}^{n} x_{i}^{k-1}
$$

where: $R$ is the number of rules, $x_{i}$ is the number of rating scales for each indicator and $k$ is the number of indicators with $i=1,2, \ldots, n$

- Machine interfaces: fuzzy interface machines integrate a collection of fuzzy inputs that are defined as a number of outputs individually.

- Defuzzifier: converts fuzzy output to crips output. The defuzzier process in this study uses the centroid method, with the following formulations:

$$
Z^{*}=\frac{\int \mu_{c}(z)^{*} z d z}{\int \mu_{c}(z) d z}
$$

where $\mathrm{Z} *$ is the center of the fuzzy region

The graphical representation of the fuzzy membership function is presented in Figure 1

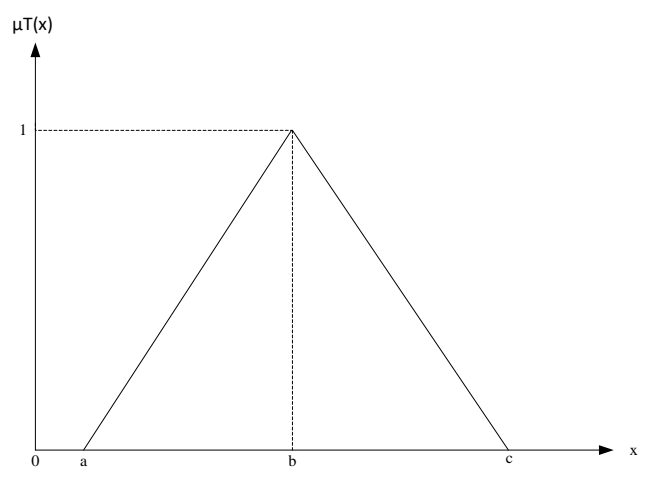

FIGURE 1: Fuzzy membership function
In this section, the process of green supplier selection performance is expressed using fuzzy inference system. The type of fuzzy control used in this study is the mamdani fuzzy control type. The steps by step procedure used in this study are as follows:

A. Set up a database, this is done by identifying green supplier selection criteria in the potato chips agroindustry. The supplier criteria assessed are obtained based on information from the quality manager and inventory warehouse manager in the potato chips agroindustry where the research was conducted.

B. Prepare input and output data, which consists of:

- Identify fuzzy membership function for input green supplier selection criteria.

- Identify fuzzy membership function for output in the form of green supplier performance.

C. Design and run the structure of the FIS model. This part includes:

- Design fuzzy rules in general.

- Run the FIS module in the MATLAB 2014a program.

Obtain supplier ratings based on the FIS module.

The method used in this study follows the research stages in Figure 2

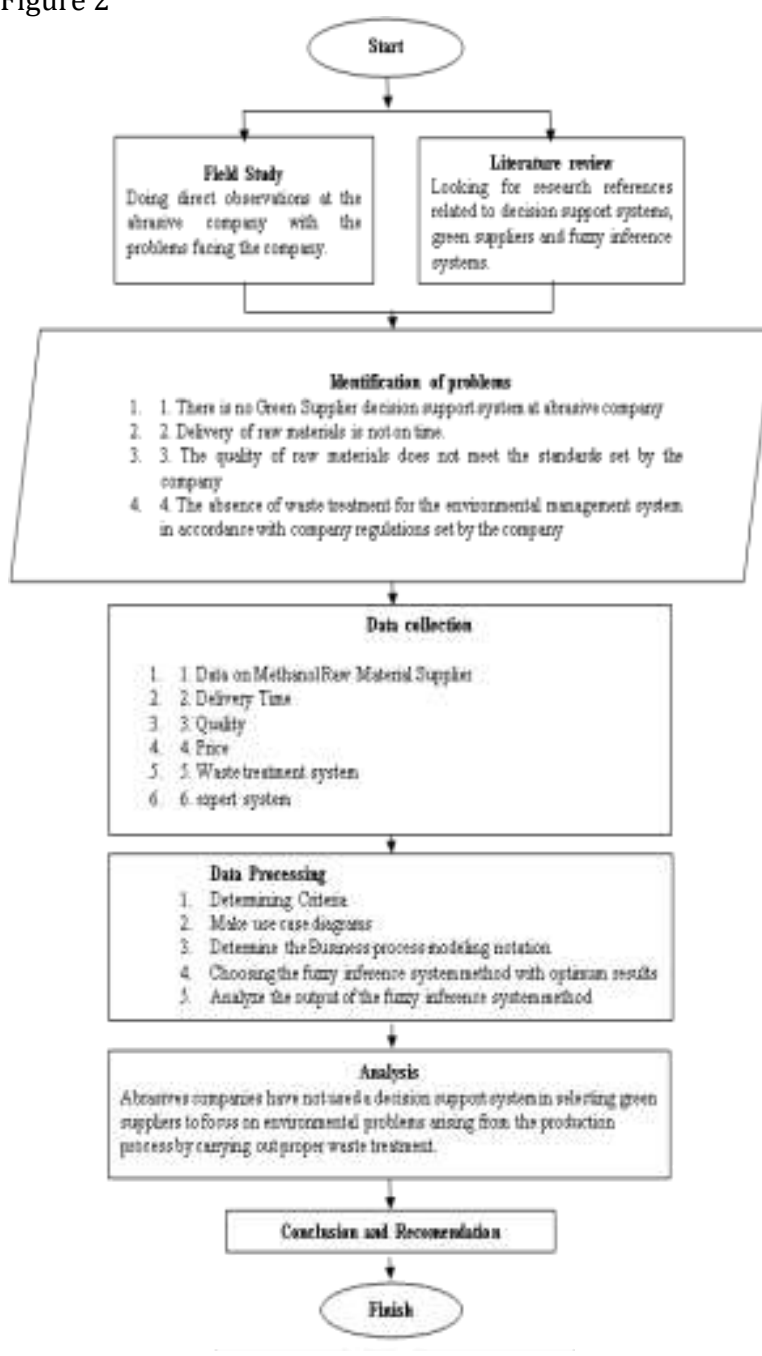

FIGURE 2: Flow chart research

\section{RESULT AND DISCUSSION}

In general, DSS is a system that is able to provide both problem-solving abilities and communication skills for semi-structured problems. In particular, DSS is a system that supports the work of a manager or a group of managers in solving semi-structured problems by 
providing information or suggestions for certain decisions [10].

\section{Business Process Modeling}

Business Process Modeling is a general diagram representing a sequence of activities implicitly focusing on a process, action and activity. The benefits of business process modeling are to facilitate an integrated understanding of the process flow and the purpose of business process modeling is to define the steps that must be taken to achieve a goal.

\section{Business Process Modeling Notation (BPMN)}

Business Process Modeling Notation (BPMN) describes a business process diagram which is based on the flowchart technique, strung together to create graphical models of business operations where there are activities and flow controls that define work sequences. System analysis is carried out to solve the system to be broken down into components so that the interaction between components and their environment. The following figure 3 shows the use case for the green supplier selection in an abrasive company.

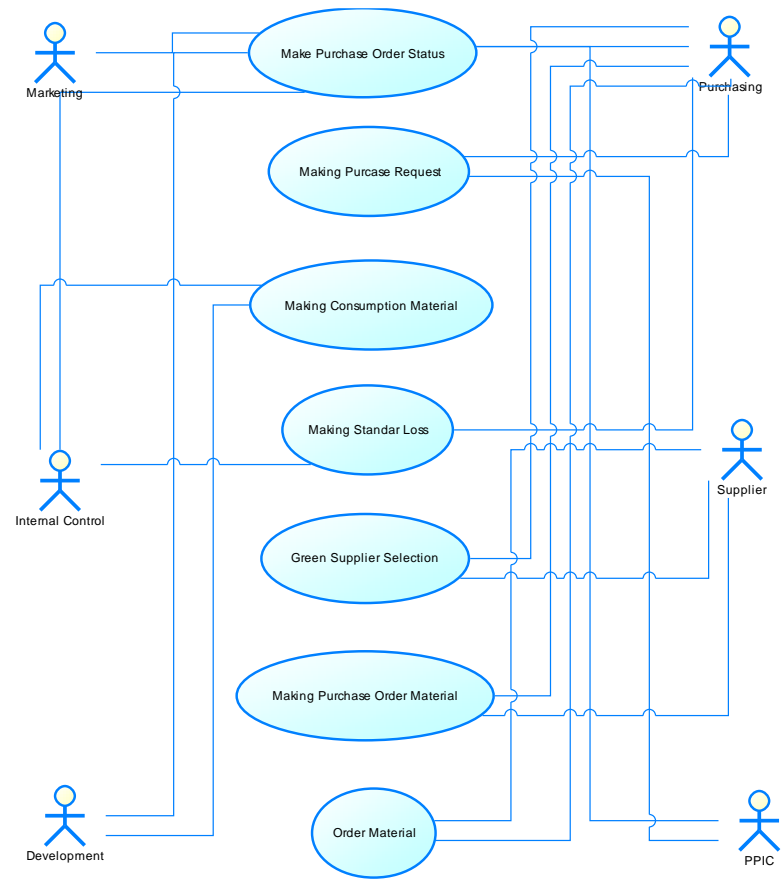

FIGURE 3: Use case green supplier selection

\section{Green Supplier Selection}

The green supplier selection process relates to environmental conditions, because the purchase of these materials must consider the environmental responsibility of the supplier in addition to traditional factors such as supplier costs, quality, delivery and environmental management. The membership degree for the price is between $18,000-23,000$ rupiah, the membership degree for reject quality is between 3 liters - 8 liters, the membership degree for environmental management is between $1-10$, and the membership degree for material delay is between 1 day - 5 days. Meanwhile, the output in this assessment is the degree of membership between $10-100$.

\section{Fuzzy Inference System}

Fuzzification is the first stage of the fuzzy inference process. At this stage the input data is received and the system determines the value of its membership function and functions to convert an analog quantity into a fuzzy input. from the membership function we can find out how many degrees of membership.

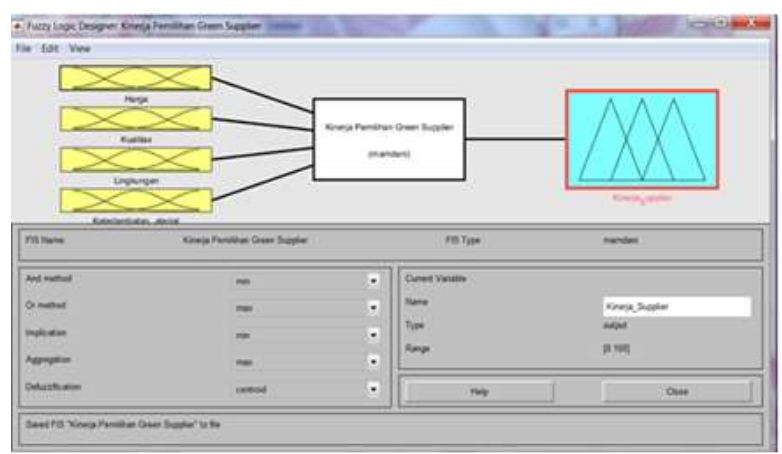

FIGURE 4: Green supplier selection performance FIS diagram.

The rules generated in this system are 81 rules. This rule is a decision that must be taken in selecting raw material suppliers in agroindustry. A value for green supplier performance indicates that the supplier is a priority supplier for the abrasive company. Figure 5 shows the basic rule produced by the system in MATLAB 2014a. example rules in the green supplier performance system are as follows:

1 If (payment is Good) and (Quality is Good) and (Arrival raw material is Good) and (ISO 14000 is Good) then (Performance is the Best)

2 If (payment is Good) and (Quality is Fair) and (Arrival raw material is Good) and (ISO 14000 is Good) then (Performance is Moderete)

3 If (payment is Good) and (Quality is Poor) and (Arrival raw material is Good) and (ISO 14000 is Good) then (Performance is Moderete)

4 If (payment is Good) and (Quality is Good) and (Arrival raw material is Fair) and (ISO 14000 is Good) then (Performance is the Best)

5 If (payment is Good) and (Quality is Fair) and (Arrival raw material is Fair) and (ISO 14000 is Good) then (Performance is Moderete)

6 If (payment is Good) and (Quality is Poor) and (Arrival raw material is Fair) and (ISO 14000 is Good) then (Performance is Poor)

7 If (payment is Good) and (Quality is Good) and (Arrival raw material is Poor) and (ISO 14000 is Good) then (Performance is Moderete)

8 If (payment is Good) and (Quality is Fair) and (Arrival raw material is Poor) and (ISO 14000 is Good) then (Performance is Poor)

9 If (payment is Good) and (Quality is Poor) and (Arrival raw material is Poor) and (ISO 14000 is Good) then (Performance is Poor)

10 If (payment is Good) and (Quality is Good) and (Arrival raw material is Good) and (ISO 14000 is Fair) then (Performance is the Best)

11 If (payment is Good) and (Quality is Fair) and (Arrival raw material is Good) and (ISO 14000 is Fair) then (Performance is Moderete)

12 If (payment is Good) and (Quality is Poor) and (Arrival raw material is Good) and (ISO 14000 is Fair) then (Performance is Poor)

13 If (payment is Good) and (Quality is Good) and (Arrival raw material is Fair) and (ISO 14000 is Fair) then (Performance is Moderete)

14 If (payment is Good) and (Quality is Fair) and (Arrival raw material is Fair) and (ISO 14000 is Fair) then (Performance is Moderete)

15 If (payment is Good) and (Quality is Poor) and (Arrival raw material is Fair) and (ISO 14000 is Fair) then (Performance is Poor)

16 If (payment is Good) and (Quality is Good) and (Arrival raw material is Poor) and (ISO 14000 is Fair) then 
(Performance is Moderete)

17 If (payment is Good) and (Quality is Fair) and (Arrival raw material is Poor) and (ISO 14000 is Fair) then (Performance is Poor)

18 If (payment is Good) and (Quality is Poor) and (Arrival raw material is Poor) and (ISO 14000 is Fair) then (Performance is Poor)

19 If (payment is Good) and (Quality is Good) and (Arrival raw material is Good) and (ISO 14000 is Poor) then (Performance is Moderete)

20 If (payment is Good) and (Quality is Fair) and (Arrival raw material is Good) and (ISO 14000 is Poor) then (Performance is Poor)

\section{Defuzzification}

At this stage the input of the defuzzification process is a fuzzy set obtained from the competition of fuzzy rules, while the resulting output is a number in the domain of the fuzzy set, so that if a fuzzy set is given in a particular domain, a crisp value must be taken. certain as the output.

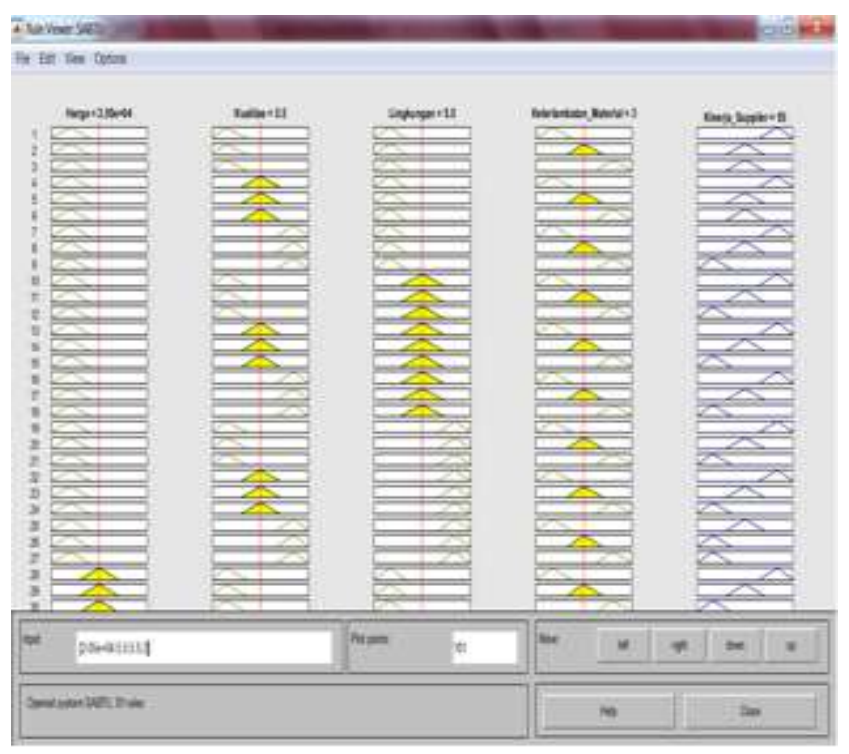

FIGURE 5: Result of optimization.

The calculation of the Matlab 2018a software above can display the fuzzy membership value in each criterion, displaying the composition of each variable by entering what can be seen in the yellow input box. The output is located in the rightmost box which is colored blue. So the output results can be directly displayed based on the input entered. The result displays a number which is the percentage of green supplier selection. The results of optimization with a price of $20.5 \%, 5.5 \%$ quality, $5.5 \%$ environment, and 3\% delay in material, the fuzzy output in selecting green suppliers with a decision-making system is $55 \%$ so that the selection of green suppliers who are currently at PT XYZ is obtained. From the data that has been obtained, the authors know the results obtained using a decision support system and the method of fuzzy inference system. For data processing used from interviews with 5 sources who handle directly the activities of purchasing and receiving goods and know the activities of the company so that they are very competent in answering questions in the interview, namely the head of warehouse, PPIC, purchasing, marketing and production.

The selection of green suppliers has six actors, namely marketing, ppic, warehouse, production, purchasing and suppliers and has six sequence charts according to the case contained in the use case diagram, namely scheduling orders, making purchase requests, selecting green suppliers, making standard losses, make purchases of materials and ordering materials. In the picture of BPMN 2.0, the stakeholders who play a role include marketing, ppic, warehouse, production, purchasing and suppliers.
The steps taken are appropriate to achieve the goal. The rules are in the form of questions written in the form of ifthen rules, the rules for determining the selection of green suppliers are obtained from the results of the informants. Based on the existing fuzzy set, we get 81 rules.

\section{CONCLUSIONS}

There are 4 criteria used in selecting the green supplier of methanol, namely price, reject quality, environmental management, material delay and the best method for decision making, namely the fuzzy inference system. Can make it easier to determine the best green supplier of raw materials. Based on the processed data obtained, to determine a decision support system, namely by getting a commitment to business processes and stakeholders who play a role in selecting green suppliers, including marketing, PPIC, warehouse, production, purchasing and suppliers so that input for supplier selection is seen from the criteria and The calculation is carried out using the fuzzy inference system method for the selection of green suppliers. In carrying out the fuzzy inference system, namely creating input and output variables, determining the degree of membership based on input and fuzzy sets, determining $\alpha$-predicates, affirming in order to obtain output solutions so as to get the result that the price is $20.5 \%$, quality is $5.5 \%$, environment is $5.5 \%$, and material delay of $3 \%$, the result of optimization of supplier performance in selecting green suppliers with a decisionmaking system is $55 \%$

\section{REFERENCES}

[1] S. Maryam and A. J. Pratama, "Analisis Pemilihan Supplier pada Proses Procurement di PT. M3 Ketapang Sejahtera dengan Metode Fuzzy Ahp dan Software Smartpicker," Penelitian dan Aplikasi Sistem dan Teknik Industri, vol. 10, no. 1, p. 182876.

[2] D. I. Handayani, "Seleksi Suplier Bahan Baku dengan Pendekatan Multi Attribut Decision Making," Penelitian dan Aplikasi Sistem dan Teknik Industri, vol. 9, no. 2, p. 182856, 2015.

[3] U. Effendi, C. Dewi, and S. Mustaniroh, "Evaluation of supply chain performance with green supply chain management approach (GSCM) using SCOR and DEMATEL method (case study of PG Krebet Baru Malang)," in IOP Conference Series: Earth and Environmental Science, 2019, vol. 230, no. 1, p. 012065: IOP Publishing.

[4] A. Y. Pradipta and A. Diana, "Sistem Penunjang Keputusan Pemilihan Supplier pada Apotek dengan Metode AHP dan SAW (Studi Kasus Apotek XYZ)," Prosiding SISFOTEK, vol. 1, no. 1, pp. 107-114, 2017.

[5] L. M. Yulyantari, S. Kom, I. P. W. ADH, and S. Kom, Manajemen Model pada Sistem Pendukung Keputusan. Penerbit Andi, 2019.

[6] C. Vercellis, Business intelligence: data mining and optimization for decision making. Wiley Online Library, 2009.

[7] A. Amindoust, S. Ahmed, A. Saghafinia, and A. Bahreininejad, "Sustainable supplier selection: A ranking model based on fuzzy inference system," Applied soft computing, vol. 12, no. 6, pp. 1668-1677, 2012.

[8] E. H. Mamdani and S. Assilian, "An experiment in linguistic synthesis with a fuzzy logic controller," International journal ofman-machine studies, vol. 7, no. 1, pp. 1-13, 1975.

[9] V. Jain, "Evaluation of the supplier performance using an evolutionary fuzzy-based approach," Journal of Manufacturing Technology Management, vol. 15, no. 8, pp. 735-744, 2004.

[10] A. Whetyningtyas, "Peranan decision support system (dss) bagi manajemen selaku decision maker," Jurnal Analisis Manajemen, vol. 5, no. 1, pp. 102-108, 2011. 